\title{
Comparison of social support network and expectation of care among elderly persons with different home arrangements
}

Leila Auxiliadora José de Sant'Anal,2 (ID Maria José $D^{\prime}$ Elboux' (D)

\section{Abstract}

Objective: To compare the social support network and expectation of care among elderly persons who live alone and those who live with others. Method: A cross-sectional study with 348 elderly people living in the community in the municipal region of Várzea Grande, Mato Grosso, Brazil was performed. The elderly were interviewed using a questionnaire composed of socio-demographic issues; evaluation tools of basic and instrumental activities of daily living; and care expectation and perceived social support network. The data were submitted to descriptive and comparative statistical analysis, the chi-squared test or Fisher's exact test at a significance level of 5\%. Results: Most of the interviewees were younger elderly women. Of these, $14.66 \%$ lived alone and $85.34 \%$ lived with other people, with mainly bi-generation family arrangements. The majority stated that they had fair health, had up to two diseases, were dependent in instrumental activities of daily living Keywords: Health of the Elderly. Social Support. Caregivers. and independent in self-care activities. Elderly persons who lived with others relied on their family, and the expectation of care was aimed at a daughter or daughter-in-law; while those who lived alone expected to rely on neighbors or friends to help with their tasks, if needed. Conclusion: Family members are the greatest providers of support and care, and the elderly hope to count on them when they need help in carrying out basic and instrumental activities of daily living.

\footnotetext{
Universidade Estadual de Campinas (UNICAMP), Faculdade de Ciências Médicas (FCM). Programa de Pós-graduação em Gerontologia. Campinas, SP, Brasil.

2 Escola de Saúde Pública do Estado de Mato Grosso (ESP/MT), Secretaria de Estado de Saúde de Mato Grosso (SES/MT). Cuiabá, MT, Brasil.
} 


\section{INTRODUCTION}

Types of protection against the daily difficulties faced by the elderly can be created through bonds established over the years, which form spontaneous and reciprocal networks of relationships that can provide individual and collective well-being. Such relationships constitute an informal social support network in which feelings of affect, protection, security, common and mutual care, the socialization of knowledge and information are cultivated among its members ${ }^{1-7}$.

Individuals establish bonds that form a social support network, which can offer material, affective, informative support or help with social interaction in old age, representing an important factor in preventing vulnerability and isolation among the elderly ${ }^{3,8-10}$.

Support is usually provided by those with whom links have been maintained, such as family, friends, neighbors, and former co-workers, making up the informal social support network. In this context, the family occupies the main place of support in the care of the elderly ${ }^{11-15}$.

The social network is effective in daily social relations, taking the form of mutual and concrete support in financial, psychological and social contexts $^{16,17}$. Sometimes, this is restricted to family members, whether in urban or rural areas, but it is in the latter that the relationship of daily care is most facilitated, due to geographical proximity ${ }^{14,18}$.

A study on the representation of old age shows that the family is a support for experiencing a positive old age and a space for exchanges and mutual help, where shelter, protection and the maintenance of health is found ${ }^{19}$. In this sense, the elderly not only feel that others are interested in them and will be available when they need them, but also receive satisfaction regarding existing relationships ${ }^{8,19,20}$, increased sociability and the creation of a possible influence on their physical, cognitive and psychological functionality ${ }^{3,4,6}$.

Friendships among the elderly are highly beneficial as they are free choices that meet their affective and dialogue needs and can help in solving everyday issues ${ }^{9}$. However, studies show that it is with the family that they maintain their main and closest relationships, providing social support, material help and support in activities of daily living, culture, leisure and care $^{2,9,13,20,21}$.

There are elderly people who need help from someone in performing certain tasks, especially those with the condition of dependence, lack of autonomy and other vulnerabilities. The social support network exists to provide them with personal care, hygiene and food when they are affected by disabling diseases ${ }^{2,15}$ or bedridden ${ }^{14}$.

Many elderly persons are faced with an inadequate social and health service structure, and for most of these individuals it is only the family that provides support and help. Thus, the identification and characterization of the existing social support network in communities is important, as are studies that can support the development of actions aimed at the care and support of the elderly, families and caregivers.

With the aim of supporting the creation of care policies for the elderly population and contributing to the knowledge and guiding of new research, this study aimed to compare the social support network and the expectation of care of elderly persons who live alone and those who live with others.

\section{METHOD}

A cross-sectional, descriptive and comparative study was performed with community-dwelling elderly persons treated at Basic Health Units (BHUs) in the city of Várzea Grande, Mato Grosso, Brazil.

To reflect the diversity of living and family arrangements of the population, elderly people from different areas were recruited - one in a central region and the other in a greener area. In consultation with the Municipal Health Department, BHUs located in the neighborhoods of Souza Lima and Água Vermelha were selected. From these units, elderly people living in green, riverside and urban areas, treated by the Community Health Agents Program (CHAP) were interviewed, as described below: 
BHU Souza Lima: covers green, urban and riverside areas, and has nine areas served by Community Health Agents (CHAs) in seven neighborhoods: Bonsucesso, Gilson de Barros Housing Estate, Gonçalo Botelho, Pai André, Parque Boa Vista, Souza Lima and Vale Verde.

BHU Água Vermelha: covers the urban area and has two teams, totaling $12 \mathrm{CHAs}$ in five neighborhoods: Água Vermelha, Jardim Glória I, Jardim Marajoara, Jardim Paula I and II. In this unit, eight $\mathrm{CHAs}$ collaborated in the data collection process, six from the Água Vermelha Team and two from the Jardim Glória I Team. Although data were not collected in the areas of all the agents, all the neighborhoods covered were represented.

At the time of data collection, which took place from February to September 2017, there was no systematic registration of users accompanied by the CHAPs of the units. Thus, the sample calculation was performed based on the number of appointments carried out: 362 elderly persons at BHU Souza Lima and 450 at BHU Água Vermelha. In this study, the following elderly persons were eligible: noninstitutionalized individuals aged 60 years and over, attended by the selected BHUs, with whom it was possible to establish communication (listening and speaking comprehension) for the interview.

The sample size calculation was $50 \%$ of the registered elderly population, based on a $95 \%$ confidence level and 5\% margin of error, resulting in 208 samples from BHU Água Vermelha and 187 samples from BHU Souza Lima. The sample participants were selected for convenience, considering the difficulty of locating addresses, obtaining the agreement of respondents without a CHA present, and the fact that not all of those from BHU Água Vermelha were available to follow or collect data.

A total of 164 (36.4\%) elderly persons from BHU Água Vermelha and 191 (52.7\%) from BHU Souza Lima met the eligibility criteria, totaling 355 elderly, representing $43.8 \%$ of the total registered with the CHAP; of these 348 questionnaires were validated for the study analysis.
Most interviews were conducted at home; at BHU Souza Lima, there were also meetings with the elderly after group meetings and appointments. Eight $\mathrm{CHAs}$ from each unit were involved in the data collection process, five of whom collaborated in recruitment and interviewing, and three of whom participated in recruitment only, at both BHU Souza Lima and Água Vermelha. All collaborators participated in a prior training program on the research protocol, objectives and procedures.

The data collection instrument was created with questions of the protocols used in the following studies: the Frailty of the Brazilian Elderly (or FIBRA) of the Postgraduate Program in Gerontology of the Medical Sciences School of the Universidade Estadual de Campinas (or FCM/UNICAMP) ${ }^{22}$, and Welfare and Aging (or SABE), coordinated by the Pan American Health Organization/World Health Organization (PAHO/WHO) in Brazil, conducted by the School of Public Health of the Universidade de São Paulo (or USP) ${ }^{23}$. It was considered valid, since the protocols of these studies were built, applied and evaluated by specialists in the area of elderly health and epidemiology.

For this study, the following variables were selected: sociodemographic; living arrangements; selfrated health and self-reported illnesses; functional capacity; expectation of care and perceived support, as described below:

The sociodemographic variables were composed of self-reported responses: a) age: number of years calculated from date of birth to the date of the interview, subsequently grouped into two age groups (60 to 74 years; 75 years and over); b) gender: two categories (male; female); c) marital status: selfreported, with four categories (married/living with a partner, divorced, separated/unmarried, single, widowed); d) educational level: calculated in years of schooling and grouped into four categories $(<1$; 1-4; 5-8; >8); e) currently working: yes; no; f) retired/ pensioner: including beneficiaries of the Continuous Cash Benefit Program (or BPC), in four categories (receive pension; receive bereavement allowance; receive pension and bereavement allowance; does not receive either). 
The living arrangement variable was identified based on the answers to the questions: Please, including yourself, tell me how many people live in your home. Based on this the following classifications were produced: a) living condition: alone; cohabiting; b) family arrangement: when the elderly person lived with someone, the following question was asked What is your degree of kinship? Based on the responses, the individuals were regrouped according to the composition of the cohabitants.

Health covered: a) self-assessment of health: responses were grouped into three categories (very good/good; fair; poor/very poor); b) number of selfreported diseases: it was asked if a doctor had ever diagnosed the interviewee with one or more of the following diseases: heart disease (angina, myocardial infarction, heart attack, etc.); high blood pressure/ hypertension; stroke/ cerebrovascular accident/ ischemia; diabetes mellitus; malignant tumor/ cancer; arthritis or rheumatism; lung (bronchitis, emphysema etc); depression; osteoporosis, and the answers were then grouped by number of diseases into two categories ( 0 to $2 ; 3$ or more).

Functional capacity was assessed as follows: a) Instrumental Activities of Daily Living (IADL) through the Lawton and Brody Scale (using the telephone; using transportation; shopping; preparing food; doing household chores; using medication; handling money) ${ }^{24}$; b) Basic Activities of Daily Living (BADL) through the Katz Scale (taking a bath; dressing; using the toilet; transference; controlling the sphincter; feeding oneself) ${ }^{24,25}$. Both Activities of Daily Living (ADL) were grouped as independent, partially dependent and totally dependent, and later regrouped as dependent and independent for statistical analysis.

The expectation of care variable was assessed based on the need for help with ADL. Beginning with the question Ifyou need or will need help doing any of the above, do you have anyone you can count on? The answers were dichotomous: yes or no for each item (spouse, daughter or daughter-in-law, son or son-in-law, other relative, neighbor or friend, paid professional).
Perceived social support was assessed based on five questions: Would you say that you have several people to talk to when you are lonely?; Would you say you meet up with and talk to friends and family?; Would you say that it is easy for you to find people who can help you with your tasks if you become ill?; Would you say you have someone to count on when you need a suggestion on how to deal with a problem?; and Would you say you have at least one person whose opinion you fully trust? 'The answers had four categories: never; sometimes; most of the time; always.

In the data organization and analysis phase, following the interviews and conferring of the answers in the protocol, the data were stored in an Excelspreadsheet, checked using the filter tool, and all the questionnaires were reviewed, comparing them with the spreadsheet records (one by one). One-dimensional exploratory analysis and absolute (n) and percentage (\%) frequencies were used.

In the two-dimensional analysis the chi-squared or Fisher exact tests were used at a 5\% significance level $(p<0.05)$ to assess the association between living conditions (alone or cohabiting) and the age and bealth variables of the elderly.

The study complied with the requirements of National Health Council Resolutions no 466/2012 and $n^{\circ} 510 / 2016$. The participants signed a Free and Informed Consent Form (FICF) and the project was approved by the Research Ethics Committee of the Universidade Estadual de Campinas (UNICAMP), under opinion no. 1.995.932, on April 3, 2017.

\section{RESULTS}

The study showed that the majority of respondents $(\mathrm{N}=348)$ were women under 75 years of age, with an average age of $70.1( \pm 7)$ years; the age range ranged from 60 to 91 . Most of the interviewees lived with other people, with spousal and bigenerational relationships predominating, which includes spouses, sons and daughters, sons-in-law and daughters-inlaw (Table 1). 
Table 1. Sociodemographic, health and functionality characteristics of the elderly $(\mathrm{N}=348)$. Várzea Grande, Mato Grosso, 2017.

\begin{tabular}{|c|c|c|}
\hline Variables & Categories & $\mathrm{n}(\%)$ \\
\hline \multirow[t]{2}{*}{ Age (years) } & 60 to 74 & $256(73.6)$ \\
\hline & 75 or more & $92(26.4)$ \\
\hline \multirow[t]{2}{*}{ Gender } & Male & $132(37.9)$ \\
\hline & Female & $216(62.1)$ \\
\hline \multirow[t]{4}{*}{ Marital Status } & Married or living with a partner & $200(57.5)$ \\
\hline & Divorced, Separated, or Unmarried & $24(6.9)$ \\
\hline & Single & $28(8.1)$ \\
\hline & Widowed & $96(27.6)$ \\
\hline \multirow[t]{4}{*}{ Schooling } & $<1$ & $57(16.4)$ \\
\hline & 1 to 4 & $191(54.9)$ \\
\hline & 5 to 8 & $74(21.3)$ \\
\hline & $>8$ & $26(7.5)$ \\
\hline \multirow[t]{2}{*}{ Work } & Yes & $109(31.3)$ \\
\hline & No & $239(68.7)$ \\
\hline \multirow{4}{*}{$\begin{array}{l}\text { Pension/ } \\
\text { Bereavement allowance }\end{array}$} & Pension & $224(64.4)$ \\
\hline & Bereavement allowance & $36(10.3)$ \\
\hline & Pension and Bereavement allowance & $24(6.9)$ \\
\hline & Does not receive either & $64(18.4)$ \\
\hline \multirow[t]{2}{*}{ Living Conditions } & Alone & $51(14.7)$ \\
\hline & Lives with someone & $297(85.3)$ \\
\hline \multirow[t]{10}{*}{ Living Arrangement } & Spouse & $82(27.6)$ \\
\hline & Son/Daughter & $24(8.1)$ \\
\hline & Grandson/Granddaughter & $19(6.4)$ \\
\hline & Other family member & $7(2.4)$ \\
\hline & Spouse, son/daughter/spouse, son/daughter, son-in-law or daughter-in-law & $60(20.2)$ \\
\hline & $\begin{array}{l}\text { Spouse, son/daughter, son-in-law or daughter-in-law, grandchild/spouse, } \\
\text { son/daughter, grandchild/ spouse, son-in-law or daughter-in-law, } \\
\text { grandchild/spouse, son/daughter, grandchild, other unpaid family member }\end{array}$ & $45(15.2)$ \\
\hline & $\begin{array}{l}\text { Spouse, son/daughter, parent/spouse, son/daughter, grandchild, siblings, } \\
\text { spouse, grandchild, stepson/daughter, spouse, grandchild }\end{array}$ & $19(6.4)$ \\
\hline & $\begin{array}{l}\text { Son/daughter, son-in-law or daughter-in-law, Son/daughter, son-in-law } \\
\text { or daughter-in-law, grandchild, son/daughter, grandchild/son-in-law or } \\
\text { daughter-in-law, grandchild, other family member }\end{array}$ & $29(9.8)$ \\
\hline & $\begin{array}{l}\text { Son/daughter, siblings/son/daughter, other family member /grandchild, } \\
\text { other family member }\end{array}$ & $5(1.7)$ \\
\hline & Other cohabitants $*$ & $7(2.4)$ \\
\hline \multirow[t]{3}{*}{ Health } & Good/very good & $97(27.9)$ \\
\hline & Fair & $210(60.4)$ \\
\hline & Poor/Very poor & $41(11.8)$ \\
\hline \multirow[t]{2}{*}{ Diseases } & 0 to 2 & $259(74.4)$ \\
\hline & 3 or more & $89(25.6)$ \\
\hline \multirow[t]{2}{*}{ IADL ** } & Dependent & $201(57.8)$ \\
\hline & Independent & $147(42.2)$ \\
\hline \multirow[t]{2}{*}{$\mathrm{BADL}^{* * *}$} & Dependent & $49(14.1)$ \\
\hline & Independent & $299(85.9)$ \\
\hline
\end{tabular}

* Stepchildren, siblings, parents, other paid or unpaid family members; **Instrumental Activities of Daily Living (IADL); ***Basic Activities of Daily Living (BADL). 
The elderly described themselves as having fair health conditions $(60.35 \%)$ and reported the presence of up to two diseases $(74.4 \%)$, reflecting a profile of non-multimorbidity. The evaluation of IADL found dependence in all activities in $57.8 \%$ of the elderly. For activities involving self-care (BADL), most of the elderly $(85.9 \%)$ were independent. Cohabitation, a condition reported by most respondents, was not correlated with age, health, number of diseases or functionality (Table 2).

Regarding the expectation of care, the elderly who lived with someone expected to rely, firstly on the help of their daughter or daughter-in-law, followed by their son or son-in-law, and then their spouse (Table 3).

Table 2. Comparison between the living conditions of the elderly with sociodemographic variables, health and functionality (N=348). Várzea Grande, Mato Grosso, 2017.

\begin{tabular}{|c|c|c|c|c|}
\hline \multirow{2}{*}{ Variables } & & Lives alone & Lives with someone & \multirow{2}{*}{$p^{*}$} \\
\hline & & $\mathrm{n}(\%)$ & $\mathrm{n}(\%)$ & \\
\hline \multirow[t]{2}{*}{ Age (years) } & 60 to 74 & $34(13.3)$ & $222(86.7)$ & \multirow{2}{*}{0.2997} \\
\hline & 75 or more & $17(18.5)$ & $75(81.5)$ & \\
\hline \multirow[t]{3}{*}{ Health } & Good/Very good & 18 (18.6) & 79 (81.4) & \multirow{3}{*}{0.2267} \\
\hline & Fair & $30(14.3)$ & $180(85.7)$ & \\
\hline & Poor/Very poor & $3(7.3)$ & $38(92.7)$ & \\
\hline \multirow[t]{2}{*}{ Diseases } & 0 to 2 & $40(15.4)$ & $219(84.6)$ & \multirow{2}{*}{0.5919} \\
\hline & 3 or more & $11(12.4)$ & $78(87.6)$ & \\
\hline \multirow[t]{2}{*}{ IADL** } & Dependent & $23(11.4)$ & $178(88.6)$ & \multirow{2}{*}{0.0676} \\
\hline & Independent & $28(19.1)$ & $119(81)$ & \\
\hline \multirow[t]{2}{*}{ BADL*** } & Dependent & $4(8.2)$ & 45 (91.8) & \multirow{2}{*}{0.2427} \\
\hline & Independent & $47(15.7)$ & $252(84.3)$ & \\
\hline
\end{tabular}

* Chi-squared test with a $5 \%$ level of significance ( $p<0.05)$; $* *$ Instrumental Activities of Daily Living (IADL); ***Basic Activities of Daily Living (BADL).

Table 3. Comparison between living conditions and on whom the elderly can rely ( $\mathrm{N}=348)$. Várzea Grande, Mato Grosso, 2017.

\begin{tabular}{|c|c|c|c|c|}
\hline \multirow[t]{2}{*}{ Variables* } & & \multirow{2}{*}{$\begin{array}{l}\text { Lives alone } \\
\mathrm{n}(\%)\end{array}$} & \multirow{2}{*}{$\begin{array}{l}\text { Lives with someone } \\
\mathrm{n}(\%)\end{array}$} & \multirow[t]{2}{*}{$p^{* *}$} \\
\hline & & & & \\
\hline \multirow[t]{2}{*}{ Spouse } & Yes & $6(3.3)$ & $176(96.7)$ & \multirow{2}{*}{$<0.001$} \\
\hline & No & $44(27)$ & $119(73)$ & \\
\hline \multirow[t]{2}{*}{ Daughter or daughter-in-law } & Yes & $33(12.3)$ & $236(87.7)$ & \multirow{2}{*}{0.0429} \\
\hline & No & $17(22.4)$ & $59(77.6)$ & \\
\hline \multirow[t]{2}{*}{ Son or son-in-law } & Yes & $23(10.2)$ & $202(89.8)$ & \multirow{2}{*}{0.0043} \\
\hline & No & 27 (22.1) & $95(77.9)$ & \\
\hline \multirow[t]{2}{*}{ Other relative } & Yes & $24(14)$ & $147(86)$ & \multirow{2}{*}{0.8960} \\
\hline & No & $26(15.1)$ & $146(84.9)$ & \\
\hline \multirow[t]{2}{*}{ Neighbor or friend } & Yes & 29 (15.6) & $157(84.4)$ & \multirow{2}{*}{0.6358} \\
\hline & No & $21(13.2)$ & $138(86.8)$ & \\
\hline \multirow[t]{2}{*}{ Paid professional } & Yes & 16 (19.1) & $68(81)$ & \multirow{2}{*}{0.2359} \\
\hline & No & $34(13)$ & $227(87)$ & \\
\hline
\end{tabular}

* Questions regarding expectation of care were answered as follows: 347 for son or son-in-law; 343 for another relative; 345 for other members of family; $* *$ Chi-squared test at $5 \%$ significance level $(p<0.05)$. 
The data show that most elderly persons always had someone to talk to, met with friends and family, and had an easy time finding people to help them if they got sick, as well as asking for advice or dealing with a problem. However, there was no significant difference between the elderly who lived alone and those who lived with someone (Table 4).

Table 4. Comparison between the living conditions of the elderly and the perceived support network ( $N=348)$. Várzea Grande, Mato Grosso, 2017.

\begin{tabular}{|c|c|c|c|}
\hline Variables* & $\begin{array}{l}\text { Lives alone } \\
\mathrm{n}(\%)\end{array}$ & $\begin{array}{l}\text { Lives with someone } \\
\mathrm{n}(\%)\end{array}$ & $p^{* *}$ \\
\hline \multicolumn{4}{|c|}{$\begin{array}{l}\text { There are several people with whom } \\
\text { you can talk when you feel alone }\end{array}$} \\
\hline Never & $1(20)$ & $4(80)$ & 0.5733 \\
\hline Sometimes & $12(15.8)$ & $64(84.2)$ & \\
\hline Most of the time & $11(18.3)$ & $49(81.7)$ & \\
\hline Always & $27(13)$ & $180(87)$ & \\
\hline \multicolumn{4}{|c|}{ Meet and chat with friends and relatives } \\
\hline Never & $0(0)$ & $4(100)$ & 0.2063 \\
\hline Sometimes & $20(21.5)$ & $73(78.5)$ & \\
\hline Most of the time & $7(13)$ & $47(87)$ & \\
\hline Always & $24(12.3)$ & $171(87.7)$ & \\
\hline \multicolumn{4}{|c|}{$\begin{array}{l}\text { Easy to find people that can help you with } \\
\text { your tasks, if you get sick }\end{array}$} \\
\hline Never & $3(30)$ & $7(70)$ & 0.3722 \\
\hline Sometimes & $13(15.5)$ & $71(84.5)$ & \\
\hline Most of the time & $8(17.8)$ & $37(82.2)$ & \\
\hline Always & $27(13.1)$ & $179(86.9)$ & \\
\hline \multicolumn{4}{|c|}{$\begin{array}{l}\text { Do you have someone you can count on when you } \\
\text { need a suggestion on how to deal with a problem? }\end{array}$} \\
\hline Never & $2(18.2)$ & $9(81.8)$ & 0.9499 \\
\hline Sometimes & $11(14.7)$ & $64(85.3)$ & \\
\hline Most of the time & $6(13)$ & $40(86.7)$ & \\
\hline Always & $31(14.5)$ & $183(85.5)$ & \\
\hline \multicolumn{4}{|c|}{$\begin{array}{l}\text { Would you say that you have at least least } \\
\text { one person whose opinion you fully trust? }\end{array}$} \\
\hline Never & $3(23.1)$ & $10(76.9)$ & 0.1828 \\
\hline Sometimes & $11(20.8)$ & $42(79.3)$ & \\
\hline Most of the time & $6(20)$ & $24(80)$ & \\
\hline Always & $31(12.4)$ & $219(87.6)$ & \\
\hline
\end{tabular}

*Questions were answered as follows: 348 for the first; 345 for the third; 346 for the others; ${ }^{* *}$ Chi-squared test at $5 \%$ significance level $(p<0.05)$. 


\section{DISCUSSION}

The socio-demographic profile of the elderly presented characteristics similar to other studies, i.e. a predominance of women ${ }^{4,26}$, who were younger than $75^{1,4,18,27-30}$, cohabited with others ${ }^{4,26,28,30}$, had up to two diseases, 26-28 and were independent for BADL (85.92\%). It is common, as the SABE study showed, that the development of dependence is greater for women $(33.2 \%)$, the elderly $(59.46 \%)$ and widowers $(37.3 \%)^{4}$.

There was no correlation between whether or not the elderly lived with someone and age, health, number of diseases or functionality. However, the data regarding the evaluation of dependence for BADL and IADL followed the same trend as the results of other studies ${ }^{28-30}$

Rabelo and $\mathrm{Neri}^{28}$ found that elderly persons living with someone exhibited total independence for BADL (96.3\%) and IADL (58.2\%) and less social involvement $(65.7 \%)$ among the oldest elderly persons. Elias, Marzola and Molina ${ }^{30}$ reported in their study ( $\mathrm{N}=637$ ) that $20.3 \%$ of the elderly lived alone and that poor family functionality was associated with single-person living conditions.

Analysis of information from the National Health Survey with individuals aged 60 years or older $(\mathrm{N}=11,967)$ shows that $15.3 \%$ of elderly persons in Brazil live alone. This condition was $29 \%$ higher for women and prevalent in nearly $1 / 5$ of individuals aged 75 and older ${ }^{29}$.

Almost $1 / 3$ of those who lived alone complained of suffering from an illness in the two weeks prior to the interview, the majority self-reported difficulties with IADL; falls (previous 12 months) and worse eating habits are also related to the elderly who live alone ${ }^{29}$. Most of the elderly lived with someone else $^{1,27,28,30,31}$ and, among their families, across generations, establish a comfortable reciprocity in giving and receiving help, especially material and emotional support ${ }^{32}$.

In the correlation between expectation of care and living conditions, data showed the centrality of the family and care provided primarily by a daughter or daughter-in-law; followed by a son or son-in-law; and subsequently by a spouse, corroborating the studies by Souza et al. ${ }^{1}$, since the expectation of care is aimed at family members. Oliveira et al. ${ }^{27}$ point out that $89.12 \%$ of the elderly report having an expectation of care; $44 \%$ expect to be cared for by only one person, often their spouse, who is also usually an elderly person. Among those who live alone, there is a three times greater risk of the absence of an expectation of care.

Lins et al. ${ }^{33}$ report that caregivers are mostly women $(77 \%)$, spouses $(39.9 \%)$ and reside with the elderly (85.7\%). Another study indicates that caregivers tend to be women $(40.4 \%)$; sons or daughters $(56.3 \%)$, spouses $(13 \%)$ and friends, neighbors, and those close to or who spend time with the elderly $(10.1 \%)$, while $85.1 \%$ of caregivers of bedridden elderly persons live with the recipient of $\operatorname{care}^{14}$

The presence of a spouse or partner and greater involvement in social activities are indicators of better functionality and psychological health, and are less taxing upon the elderly, being particularly noticeable when the family meets the expectations of care $^{28}$.

Guedes et al. ${ }^{5}$ emphasized that informal care is most effective when offered by close relatives. On the other hand, the absence of such individuals and/or geographical distance are associated with inadequate support.

In this study, the comparison between living condition and support network, both for those who live alone and those who live with others, showed the satisfaction of the elderly with their social networks, as they reported that they can always find people to talk or help with their tasks.

Family members tend to be closer and, therefore, are considered important when it comes to emotional support ${ }^{14}$, while a satisfactory perception of family support influences mental health and stress situations, as well as providing social welfare and feelings of safety and autonomy ${ }^{28,31}$. The researchers highlight that the network composed of family and friends is larger than the family network, in relation to sons and/or daughters who do not live with the elderly. Although this network is smaller, it is that which most expressively supports the elderly ${ }^{4}$. 
Family, neighbors, friends and community are fundamental in situations of crisis and for socialization and stress reduction in general, representing an informal network and frequent provider of support in the event of the insufficiency of the social network offered by the government ${ }^{5,7}$.

One imitation of the present study was that the homogeneity of the sample, despite being carried out in different areas, makes it impossible to assess the statistical significance of the social support network in relation to the profile of the elderly interviewed. The cross-sectional design also prevents the effectiveness and dynamics of the family network from being assessed, highlighting more specific differences for the elderly and those with impaired functional capacity. Nevertheless, the results of this study may support future research.

\section{CONCLUSION}

The study population consisted mainly of women, under 75 years of age, who were independent for basic and significantly impaired for instrumental activities of daily living. Most of the elderly who lived with others had an expectation of care and exhibited confidence in those close to them to help with daily activities, when necessary, especially in relation to

\section{REFERENCES}

1. Souza DS, Berlese DB, da Cunha GL, Cabral SM, dos Santos GA. Análise da relação do suporte social e da síndrome da fragilidade em idosos. Psicologia, saúde e doenças [Internet] 2017 [acesso em 10 jun. 2018];8(2):420-33. Disponível em: http://www.scielo. mec.pt/scielo.php?script $=$ sci_arttext\&pid $=$ S164500862017000200011\&lng=pt.http://dx.doi. org/10.15309/17psd180211

2. Lemos ND, Medeiros SL. Suporte social ao idoso dependente. In: Freitas EV, Py L, organizadoras. Tratado de Geriatria e Gerontologia. 4.ed. Rio de Janeiro: Guanabara Koogan; 2017. p. 3153-66.

3. Domingues MARC, Ordonez TN, da Silva TBL. Instrumentos de avaliação de rede de suporte social. In: Freitas EV, Py L, organizadoras. Tratado de Geriatria e Gerontologia. 4.ed. Rio de Janeiro: Guanabara Koogan; 2017. p.3490-508. their children, with the daughter or daughter-in-law the main caregivers.

Despite the lack of statistical significance, social relationships were observed among the elderly, as they stated that they always found people to talk to, help with tasks and give suggestions and opinions. In general, the family was the main social support for activities of self-care or tasks outside the home, but friends and others in the community were also providers of emotional and moral support, as they represented opportunities for conversation and social interaction.

Although this was not the case for most, the proportion of elderly people who lived alone or only with their spouses and had limitations in instrumental activities was noteworthy. This living condition suggested an inadequate support network, which also failed to effectively meet the daily needs of the elderly.

A more diverse support network could overcome the problems of the inadequate social support provided by the government. It is therefore suggested that further research on social support and assistance is carried out, and it is hoped that this study, in some way, encourages the search for strategies and the implementation of care and support programs for the elderly and their caregivers.

4. Brito TRP, Nunes DPI, Duarte YAO, Lebrão ML. Redes sociais e funcionalidade em pessoas idosas: evidências do estudo Saúde, Bem-Estar e Envelhecimento (SABE). Rev Bras Epidemiol [Internet]. 2018 [acesso em 25 jun. 2019];21(Suppl 2):e180003 [15 p]. Disponível em: http://www. scielo.br/scielo.php?script=sci_arttext\&pid=S1415790X2018000300400\&lng=pt.Epub04-Fev-2019. http://dx.doi.org/10.1590/1980-549720180003.supl.2

5. Guedes MBOG, Lima KC, Caldas CP, Veras RP. Apoio social e o cuidado integral à saúde do idoso. Physis [Internet]. 2017 [acesso em 13 nov. 2018];27(4):1185-1204. Disponível em: http://www. scielo.br/scielo.php?script=sci_arttext\&pid=S010373312017000401185\&lng=en.http://dx.doi. org/10.1590/s0103-73312017000400017 
6. Rabelo DF, Neri AL. A complexidade emocional dos relacionamentos intergeracionais e a saúde mental dos idosos. Pensando Fam [Internet]. 2014 [acesso em 13 nov. 2018];18(1):138-53. Disponível em: http://pepsic. bvsalud.org/scielo.php?script=sci_arttext\&pid=S1679494X2014000100012\&lng=pt\&tlng=pt

7. Guadalupe S, Cardoso J. As redes de suporte social informal como fontes de provisão social em Portugal: o caso da população idosa. Soc Estado [Internet]. 2018 [acesso em 13 de nov. 2018];33(1):213-48. Disponível em: https://dx.doi.org/10.1590/s0102-699220183301009

8. Neri AL. Palavras-chave em Gerontologia. 4.ed. Campinas: Alínia; 2014. Rede de suporte social. p. 289-95.

9. Leite MT, Battisti IDE, Berlezi EM, Scheuer AI. Idosos residentes no meio urbano e sua rede de suporte familiar e social. Texto \& Contexto Enferm [Internet]. 2008 [acesso em 10 jun. 2018];17(2):250-7. Disponível em: http://www.redalyc.org/articulo.oa?id=71417205

10. Melchiorre MG, Chiatti C, Lamura G, Torres-Gonzales F, Stankunas M, Lindert J, et al. Social support, socioeconomic status, health and abuse among older people in seven European countries. PLoS ONE [Internet]. 2013 [acesso em 10 jun. 2018];8(1):e54856 [10 p.]. Disponível em: http://journals.plos.org/plosone/ article?id=10.1371/journal.pone.0054856

11. Shiba K, Kondo N, Kondo K. Informal and formal social support and caregiver burden: the AGES caregiver survey. J Epidemiol [Internet]. 2016 [acesso em 10 de jun. 2018];26(12):622-8. Disponível em: https://www.jstage.jst.go.jp/article/jea/26/12/26_ JE20150263/_article/-char/ja/

12. Gouveia OMR, Matos AD, Schouten MJ. Redes sociais e qualidade de vida dos idosos: uma revisão e análise crítica da literatura. Rev Bras Geriatr Gerontol [Internet]. 2016 [acesso em 17 jun. 2018];19(6):103040. Disponível em: http://www.scielo.br/pdf/rbgg/ v19n6/pt_1809-9823-rbgg-19-06-01030.pdf

13. Tarallo RS. As relações intergeracionais e o cuidado do idoso. Rev Kairós [Internet]. 2015 [acesso em 26 jan. 2019];18(19):39-55. Disponível em: http://ken. pucsp.br/kairos/article/view/26592

14. Mendes PN, Figueiredo MLF, dos Santos AMR, Fernandes MA, Fonseca RSB. Sobrecargas física, emocional e social dos cuidadores informais de idosos. Acta Paul Enferm [Internet]. 2019 [acesso em 26 de jun. 2019];32(1):87-94. Disponível em: http://www.scielo.br/scielo.php?script=sci arttext\&pid=S0103-21002019000100087\&lng=en. http://dx.doi.org/10.1590/1982-0194201900012
15. dos Anjos KF, Boery RNSO, Pereira R, Pedreira LC, Vilela ABA, Santos VC, et al. Associação entre apoio social e qualidade de vida de cuidadores familiares de idosos dependentes. Ciênc Saúde Coletiva [Internet]. 2015 [acesso em 10 jun. 2018];20(5):1321-30.

Disponível em: https://www.scielosp.org/article/ssm/ content/raw/?resource_ssm_path=/media/assets/csc/ v20n5/pt_1413-8123-csc-20-05-01321.pdf

16. Lee HS, Kim C. Structural equation modeling to assess discrimination, stress, social support, and depression among the elderly in South Korea. Asian Nurs Res [Internet]. 2016 [acesso em 02 ago. 2016];(10):182-8. Disponível em: https://www.asian-nursingresearch. com/article/S1976-1317(16)30039-1/pdf

17. Li H, Ji Y, Chen T. The roles of different sources of social support on emotional well-being among Chinese elderly. PloS ONE [Internet]. 2014 [acesso em 02 ago. 2016];9(3):e90051 [8 p.]. Disponível em: https://www.ncbi.nlm.nih.gov/pubmed/24594546

18. de Sousa FJD, Gonçalves LHT, Paskulin LGM, Gamba MA. Perfil sociodemográfico e suporte social de idosos na atenção primária. Rev Enfern UFPE on line [Internet]. 2018 [acesso em 26 jan. 2019];12(4):824-31. Disponível em: https://www.lume. ufrgs.br/handle/10183/178164

19. Brito AMM, Camargo BV, Castro A. Representações sociais de velhice e boa velhice entre idosos e sua rede social. Rev Psicol IMED [Internet]. 2017 [acesso em 26 jan. 2019];9(1):521. Disponível em: http://pepsic.bvsalud.org/ scielo.php?script $=$ sci_arttext\&pid $=$ S2175$50272017000100002 \& \operatorname{lng}=$ pt\&nrm $=$ iso

20. Santos AS, da Silveira RE, Farinelli MR. A dinâmica sociofamiliar do idoso. In: Campos ACV, Berlezi EM, Correa AHM, organizadores. Direitos do idoso: os novos desafios das políticas públicas. Ijuí: Unijuí; 2014. p.123-45.

21. Domingues MA, Ordonez TN, Lima-Silva TB, Torres MJ, de Barros TC, Florindo AA. Redes de relações sociais dos idosos residentes em Ermelino Matarazzo, São Paulo: um estudo epidemiológico. Rev Bras Geriatr Gerontol [Internet]. 2013 [acesso em 17 jun. 2018];16(1):49-59. Disponível em: http://www. scielo.br/scielo.php?script=sci_arttext\&pid=S180998232013000100006\&lng=pt. http://dx.doi. org/10.1590/S1809-98232013000100006

22. Neri AL, Guariento ME, organizadoras. Fragilidade, saúde e bem-estar em idosos: dados do estudo FIBRA. Campinas: Alínea; 2011. 
23. Lebrão ML, Laurenti R. Saúde, bem-estar e envelhecimento: o estudo SABE no Município de São Paulo. Rev Bras Epidemiol [Internet]. 2005 [acesso em 05 ago. 2016];8(2):127-41. Disponível em: http://www. scielo.br/scielo.php?script $=$ sci_arttext\&pid $=\mathrm{S} 1415$ 790X2005000200005\&lng=pt\&nrm=iso

24. Duarte YAO, Andrade CL, Lebrão ML. O Índex de Katz na avaliação da funcionalidade dos idosos. Rev Esc Enferm USP [Internet]. 2007 [acesso em 05 ago. 2016];41(2):317-25. Disponível em http://www. scielo.br/scielo.php?script $=$ sci_arttext\&pid $=\mathrm{S} 0080$ 62342007000200021\&lng=en\&nrm=iso

25. Lino VTS, Pereira SRM, Camacho LAB, Ribeiro Filho T, Busksman S. Cross-cultural adaptation of the independence in activities of daily living index (Katz index). Cad Saúde Pública [Internet]. 2008 [acesso em 07 jun. 2016];24(1):103-12. Disponível em: http://www.scielosp.org/scielo.php?pid=S0102 311X2008000100010\&script=sci_arttext\&tlng=es

26. Murata C, Saito T, Saito M, Kondo K. The Association between Social Support and Incident Dementia: A 10-Year Follow-Up Study in Japan. Int J Environ Res Public Health [Internet]. 2019 [acesso em 25 jun. 2019];16:239. Disponível em: https://www. mdpi.com/1660-4601/16/2/239

27. Oliveira DC, Neri AL, D’Elboux MJ. Ausência de expectativa de suporte para o cuidado aos idosos da comunidade. Rev Bras Enferm [Internet]. 2016 [acesso em 02 out. 2018];69(3):566-73. Disponível em: http://www.scielo.br/pdf/reben/v69n3/0034-7167reben-69-03-0566.pdf

28. Rabelo DF, Neri AL. Tipos de configuração familiar e condições de saúde física e psicológica em idosos. Cad Saúde Pública [Internet]. 2015 [acesso em 26 jun. 2019];31(4):874-84. Disponível em: http://www. scielo.br/scielo.php?script $=$ sci_arttext\&pid=S0102311X2015000400874\&lng=en.http://dx.doi. org/10.1590/0102-311X00087514
29. Negrini ELD, do Nascimento CF, da Silva A, Antunes JLF. Quem são e como vivem os idosos que moram sozinhos no Brasil. Rev Bras Geriatr Gerontol [Internet]. 2018 [acesso em 26 jan. 2019];21(5):542-50. Disponível em: http:// www.scielo.br/pdf/rbgg/v21n5/pt_1809-9823rbgg-21-05-00523.pdf

30. Elias HC, Marzola TS, Molina NPFM, de Assunção LM, Rodrigues LR, Tavares DMS. Relação entre funcionalidade familiar e arranjo domiciliar de idosos. Rev Bras Geriatr Gerontol [Internet]. 2018 [acesso em 26 jan. 2019];21(5):582-90. Disponível em: http:// www.scielo.br/pdf/rbgg/v21n5/pt_1809-9823rbgg-21-05-00562.pdf

31. Maia CML, Castro FV, da Fonseca AMG, Fernández MIR. Redes de apoio social e de suporte social e envelhecimento ativo. Int J Dev Educ Psychol [Internet]. 2016 [acesso em 04 set. 2018];1(1):293-304. Disponível em: http://infad.eu/ RevistaINFAD/OJS/index.php/IJODAEP/article/ view/279/182

32. São Paulo (Cidade). Secretaria da Saúde. Saúde da pessoa idosa: gerenciamento de cuidados para a atenção integral à saúde da pessoa idosa [Internet]. São Paulo: SMS; 2015 [acesso em 10 jul. 2019]. Disponível em: https://www. prefeitura.sp.gov.br/cidade/secretarias/upload/ saude/ems/APOSTILA $\% 20$ CURSO $\% 20$ DE $\% 20$ GERENCIAMENTO $\% 20 \mathrm{DE} \% 20 \mathrm{CUIDADOS} \% 20$ DA\%20PESSOA\%20IDOSA_CD.pdf

33. Lins AES, Rosas C, Neri AL. Satisfação com as relações e apoios familiares segundo idosos cuidadores de idosos. Rev Bras Geriatr Gerontol [Internet]. 2018 [acesso em 30 set. 2018];21(3):341-52. Disponível em: http://www.rbgg.com.br/arquivos/ proximas-publicacoes/2017-0177.pdf 